Article

\title{
A Relational Approach to How Media Engage With Their Audiences in Social Media
}

\author{
Mark Badham ${ }^{1, *}$ and Markus Mykkänen ${ }^{2}$ \\ ${ }^{1}$ Corporate Communication, Jyväskylä University School of Business \& Economics, Finland \\ 2 Department of Language and Communication Studies, University of Jyväskylä, Finland \\ * Corresponding author (mabadham@jyu.fi)
}

Submitted: 26 April 2021 | Accepted: 30 June 2021 | Published: 20 January 2022

\begin{abstract}
People are increasingly turning to social media for their news and for sharing and discussing news with others. Simultaneously, media organizations are becoming platform-dependent and posting short forms of their news on their social media sites in the hope that audiences will not only consume this news but also comment on and share it. This article joins other media and journalism studies exploring this phenomenon through a relational approach to media audiences to better understand how media organizations, particularly newspapers, are cultivating relationships with audiences via social media. Drawing on public relations theory about organization-public relationships, the article examines how news organizations nurture relationships with audiences via social media, such as through engagement and dialogic communication strategies. This article empirically examines organization-public relationships strategies (disclosure, access, information dissemination, and engagement) of nine newspapers with the largest reach in Australia, the US, and the UK. A content analysis is conducted of these newspapers' posts (total 1807) published in March 2021 on their Twitter and Facebook sites to identify and examine these strategies. Findings show that their social media accounts are predominantly used for news dissemination rather than audience engagement. The implications are that although media professionals are frequently distributing news content among their audiences via their social media sites, they are not adequately engaging with them.
\end{abstract}

\section{Keywords}

audiences; engagement; media organizations; news dissemination; organization-public relationship strategies; relational approach; social media

\section{Issue}

This article is part of the issue "New Forms of Media Work and Its Organizational and Institutional Conditions" edited by Salla-Maaria Laaksonen (University of Helsinki) and Mikko Villi (University of Jyväskylä).

(C) 2022 by the author(s); licensee Cogitatio (Lisbon, Portugal). This article is licensed under a Creative Commons Attribution 4.0 International License (CC BY).

\section{Introduction}

Audiences increasingly turn to social media as their main source of news (Newman et al., 2021, p. 10), and subsequently consume, share, and discuss news through social media. News organizations recognise this emerging practice and build business models and distribution strategies to tap into this trend. Accordingly, we position this study within media work research (Deuze, 2007; Hesmondhalgh \& Baker, 2011) that examines how news media organizations plan, produce, disseminate, and pro- mote their news content through social media (Malmelin \& Villi, 2017; Villi et al., 2016; Villi \& Noguera-Vivo, 2017). While much of media work research has examined the audience role in the creation and production of news through social media and other digital environments (Malmelin \& Villi, 2016, 2017), we limit our study to news distribution (Napoli, 2009; Oeldorf-Hirsch \& Sundar, 2012; Villi et al., 2016). We view distribution not as the media organization's dissemination (publication) of news, but rather as a collaborative effort between outlets and their audiences spreading and promoting news. 
Thus, we focus on how media organizations become involved in marketing efforts (Malmelin \& Villi, 2017) through social media to expand the reach and impact of their content. Accordingly, we treat audiences not only as consumers who passively receive media content but also as participants engaging with the content of media organizations, such as through sharing, commenting, and applying sentiment judgments to media content in social media. In doing so, they unintentionally take part in media work through the distribution and promotion of content.

However, technology platforms have added deep levels of complexity to the media work of news distribution conducted in social media (Lewis \& Molyneux, 2018). Taking these platform-dependency challenges into account, this study contributes to an emerging media-audience relational approach (Hepp, 2020; Hepp \& Loosen, 2019; Lewis et al., 2014; Picard, 2011; Villi \& Picard, 2019) which offers insight into, and argues for the importance of, news outlets' mutually beneficial relations with their audiences. However, in the literature on this approach, communication strategies to develop these mutually beneficial relations have not yet received scholarly attention. Accordingly, this study draws on relationship theory in public relations research to examine four relationship-cultivation strategies of media organizations in social media, namely disclosure, access, information dissemination, and engagement. This study examined 904 Facebook posts and 903 tweets published in March 2021 by nine of the more popular newspapers in Australia, the US, and the UK to identify and examine their use of these relationship-cultivation strategies in social media. Findings show that these newspapers predominantly made use of information dissemination strategies to cultivate relationships with audiences. This is not surprising, given that media outlets are in the business of disseminating news. However, engagement strategies were not well used, suggesting that although news outlets would like to engage more with audiences, they are not doing so.

This article is structured as follows. It begins with a discussion of platform companies' influence in media-audience relationships, followed by a brief review of current journalism research about a relational approach to media audiences. It then integrates public relations theory into this discussion to show how media organizations can nurture audience relationships through relationship cultivation strategies implemented in social media. Finally, it describes the empirical data and discusses the findings within the context of a relational approach to media work.

\section{Audience Relations via Social Media Platforms}

The way platform companies like Google and Facebook both support and muzzle media work is an issue of growing interest to media organizations (e.g., Meese \& Hurcombe, 2020). As third parties mediating, facilitat- ing, and sometimes dictating the economic relationship between media outlets and their audiences, platform companies pose both problems and opportunities for the news media. For example, they help news outlets spread their news to wider audiences and as a result this offers the potential for financial rewards for media companies, such as more advertising revenues and more digital subscriptions. However, the challenge is that closer ties between the two makes news organizations more dependent on these platforms for audience traffic (Bell, 2018; Bell \& Owen, 2017) and this restricts the media's autonomy (Gans, 1979) and its editorial independence (e.g., as the primary gatekeeper of news in society).

These platforms often change their algorithms and features, which can reduce the number of users viewing and reading news content. While new outlets' websites and apps enable them to maintain gatekeeping control over the reach and spread of their news, their social media accounts-through software features and algorithms - force some restrictions over who sees and consumes their news, which means these platform companies exercise a great deal of control over news outlets' relationships with their audiences. As observed by Hermida (2020, p. 477) "platforms, then, serve as algorithmic gatekeepers of the public's attention." These proprietary algorithms give platform companies power over the promotion and deletion or suppression of different types of news stories.

Media organizations and their audiences have contributed to the coupling of platforms with news consumption and distribution processes (Newman et al., 2021; Nielsen \& Schrøder, 2014) and this has thus embedded platforms in media-audience relations. In 2019, $55 \%$ of US adults often or sometimes obtained news from social media (predominantly Facebook; Shearer \& Grieco, 2019). Kalsnes and Larsson (2018) find that Twitter is used more to follow and share breaking news, whereas on Facebook the news often is softer and stories-based. Twitter is also defined as more newsoriented whereas Facebook is considered more as a social network and is used more for marketing purposes (Ju et al., 2014; Kalsnes \& Larsson, 2018).

Media-audience relations are very dependent on news engagement on social media platforms. In this article we focus on engagement as audience participation in user-distributed content rather than user-generated content (for previous work on user-distributed content see Villi \& Noguera-Vivo, 2017). Dutceac Segesten et al. (2020) define engagement on Facebook as constituting three distinct, yet interrelated, behaviours that influence news consumption and distribution on that platform: visual attention, news selection, and distribution. Once a user has observed a news post on Facebook (attention), that user can then select it by clicking the post to read the full story. The final engagement step involves the user sharing the post with their network of peers, which contributes to the distribution of the news on social media. Of course, a user's decision over what news to share is 
based on multiple factors, such as fear of criticism from members of social networks (Dutceac Segesten et al., 2020, p. 5).

Gaining audience attention is important. News media seek to gather more audience for their news and traffic to their online news sites through social media (Ju et al., 2014). Social media platforms like Facebook enable news outlets to use tactics such as "engineering headlines to include emotional directives for readers (to click or like and share) and creating digestible and relatable content that could be easily shared among users" (Caplan \& boyd, 2018, p. 5).

As stated above, platforms have limited media outlets' control over not only gaining attention, but also news distribution. Although news outlets traditionally controlled the dissemination of their news through their channels (e.g., printed newspapers and TV and radio broadcasts), technology has forced them to add other means of dissemination (i.e., distribution) such as via their websites, apps, and social media accounts. For clarity, we refer to dissemination as the news outlet's initial publication or broadcast of news and distribution as the post-dissemination process involving the news outlet and its audience promoting the news (such as through posting news headlines and subsequent sharing, liking, and commenting in social media), whether intentionally or not. See Figure 1 for an illustration of the positioning of dissemination, distribution, and engagement within the overall process of news production, dissemination and distribution processes adapted from Dutceac Segesten et al. (2020).

\section{A Relational Approach to Media Work With Audiences via Social Media}

Acknowledging these third-party complexities in the economic relationship between news organizations and their audiences, this study builds on an emerging relational orientation to media work in social media. Picard (2011) and Villi and Picard (2019) draw attention to innovative newspaper business models that focus on building and nurturing value-creating relationships with readers and other newspaper stakeholders. They advise media companies to adopt an audience-first strategy (Lehtisaari et al., 2018) to develop higher-level relationships with audiences based on "mutual respect and the pursuit of joint benefit" (Villi \& Picard, 2019, p. 126).

Another emerging strand of journalism research that offers insight into a media-audience relational approach is reciprocal journalism (Lewis et al., 2014) or mutually beneficial exchanges between journalists and audiences. Lewis et al. (2014) describe reciprocal journalism as "a way of imagining how journalists might develop more mutually beneficial relationships with audiences" (p. 229; see also Coddington et al., 2018). They hypothesize that reciprocal forms of journalism could be of three overlapping types: direct exchanges between journalists and audiences (e.g., one-to-one social media conversation); indirect exchanges that are more generalized, one-to-many and intended for community benefit; and sustained exchanges that have an enduring dimension, build relationships over time and lay the groundwork for future interactions (Lewis et al., p. 561). Research has shown that if journalists deliberately seek to develop mutually beneficial relationships with audiences, the public will reciprocate more positively, such as with favourable comments (Borger et al., 2016; Harte et al., 2017; Reader, 2018).

More recently, studies by Hepp (2020) and Hepp and Loosen (2019) refer to a figurational approach in which relations between journalists and audiences are "characterized by more or less congruent mutual expectations about what journalism should deliver and what audiences might expect, and the more or less mutually visible practices that emerge as a result" (Hepp \& Loosen, 2019, p. 57). However, in reality, the paradox is that although news organizations have offered a growing number of participatory spaces and features, journalists are often reluctant to engage with audiences (Hepp \& Loosen, 2019, p. 57). Holton et al. (2016) suggest that media organizations and journalists are in general reluctant to pursue relational ties with audiences, largely due to the media's in-built deference to professional autonomy (Gans, 1979). They state that "there is an enduring tension between maintaining professional control of the news information environment, as a key aspect of journalists' occupational role, and developing more dialogical relationships with users via digital media" (Holton et al., 2016, p. 851).

\section{Media Organizations' Relationship-Cultivation Strategies via Social Media}

What is missing in this emerging media-audience relational perspective are communication strategies to implement these mutually beneficial relationships in social media. Thus, to expand understanding of media work undertaken through media-audience relationships

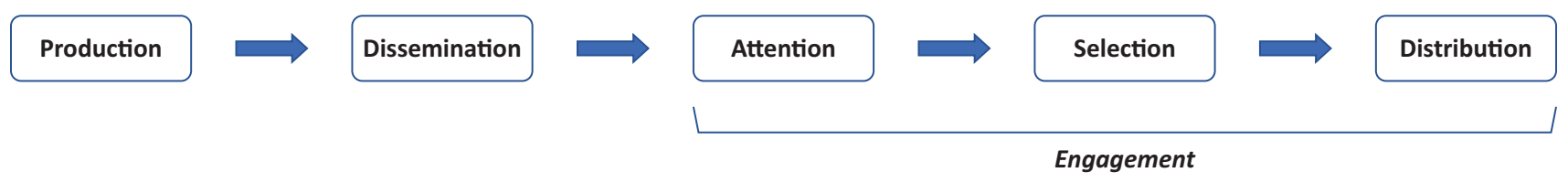

Figure 1. News production, dissemination, and engagement process on Facebook, adapted from Dutceac Segesten et al. (2020). 
operationalized via social media, this study draws on the theory about organization-public relationships (OPR; Ki $\&$ Hon, 2009) from public relations literature, the second most frequently used theory in public relations scholarship (Sallot et al., 2003). OPRs have been defined as the "(state which exists between an organization and its key publics in which the actions of either entity impact the economic, social, political, and/or cultural well-being of the other entity" (Bruning \& Ledingham, 1999, p. 160). OPR research has examined relationship antecedents, relationship outcomes, and relationship-cultivation or relationship maintenance strategies (Grunig \& Huang, 2000; Hon \& Grunig, 1999). OPR research has shown that relationships contribute to loyalty and satisfaction with an organization's products and services (Ledingham \& Bruning, 1998; Ledingham et al., 1999).

In this study, we examine media outlets' relationship-cultivation strategies, which are an organization's communication efforts aimed at nurturing mutuallybeneficial relationships with audiences (Grunig \& Huang, 2000). These strategies include positivity, disclosure, social networks, access, assurance, information dissemination, and engagement. Positivity is defined as "anything the organization or public does to make the relationship more enjoyable for the parties involved" (Hon \& Grunig, 1999, p. 14). Assurances relate to "attempts by parties in the relationship to assure the other parties that they and their concerns are legitimate" (Hon \& Grunig, 1999, p. 15). Social networks involve "organizations' and publics' sharing in solving joint or separate problems" (Hon \& Grunig, 1999, p. 14). Shin et al. (2015) define four strategies in their study of OPRs in Facebook: disclosure, access, information dissemination, and engagement. Disclosure is measured through evidence of an organization's disclosure of information about itself, such as its management structure, financial situation, and mistakes. Terms such as openness and transparency describe this dimension. Access refers to an organization's availability to the public and this can be measured through evidence of the range of contact information made available to the public. Information dissemination refers to the extent to which an organization provides information useful to its public, such as information about its products and services. Engagement refers to the extent to which an organization actively engages in conversations with its audiences and welcomes their feedback. The definition of engagement on Facebook by Dutceac Segesten et al. (2020) provided above offers further insight into this strategy.

The advent of social media shifted the emphasis in OPR scholarship from an overwhelmingly massmediated approach to a much more conversational, relationship-building approach (Kelleher, 2009). It also transitioned the conceptualization of OPR communication from "monologue (one-to-many) to dialogue (manyto-many)" (Hansen et al., 2011, p. 12). Indeed, OPR research is aided by the concept of dialogic communication (Wilcox \& Cameron, 2009). Organizations apply dialogic communication by listening to their audiences, having a positive regard for them, and being willing to change in response to audience wishes (De Bussy, 2010). Digital media, including social media, enable organizations to not only disseminate information to audiences but also interact with them through feedback or dialogic loops (Kent \& Taylor, 1998; Lillqvist \& Louhiala-Salminen, 2014).

Social media sites have been found to be much more suitable for dialogic communication and relationshipbuilding (Shin et al., 2015). Dialogic communication features in Facebook include ease of interface, usefulness of information, and links to the organization's home page (Bortree \& Seltzer, 2009; Shin et al., 2015, p. 189). However, studies have suggested that organizations are not adequately using these features for dialogic communication and relationship-building (Bortree \& Seltzer, 2009; Shin et al., 2015). Organizations also are not taking advantage of Twitter for dialogic communication and relationship-building (Lovejoy et al., 2012; Rybalko \& Seltzer, 2010). Instead, organizations predominantly are using both Facebook and Twitter for information dissemination (Shin et al., 2015).

We identify OPR strategies of disclosure and information dissemination as dimensions of uni-directional communication (Shin et al., 2015) because they represent an organization choosing to provide its public with information about itself. We consider the OPR strategy of access as a dimension between uni-directional and dialogic communication; on the one hand, the public can gain access to the organization's contact information and thus communicate one-on-one with the organization, yet, on the other hand, the organization does not necessarily proactively engage in stimulating and maintaining conversations with the public when providing this information. The OPR strategy of engagement is considered a two-directional dialogic communication (Shin et al., 2015, p. 191) because it represents the organization's purposeful stimulation and maintenance of conversations.

\section{Method and Data}

In this study we address the research question: How do newspapers nurture relationships with audiences through their social media sites? To examine this question, we conducted a content analysis of Facebook and Twitter posts of nine newspapers located in Australia, the US, and the UK to identify OPR strategies. We selected these countries because of their similarities as large Western democratic societies with an Anglosphere background. These selected newspapers were among the five largest within their countries by circulation, located in three of the largest Anglosphere countries, and included: The New York Times (US), New York Post (US), USA Today (US), The Wall Street Journal (US), The Daily Telegraph (Australia), The Sydney Morning Herald (Australia), The Courier-Mail (Australia), Herald 
Sun (Australia) and Metro (UK). The selected US newspapers reach 426,000 to 1.6 million readers. Their combined reach is 3.5 million readers (Statista, 2019). The circulation of the UK-based newspaper Metro was 1.4 million in 2020 (Mayhew, 2020). Detailed information on the circulation of Australian newspapers is currently difficult to obtain. The total number of selected Australian newspaper audiences' readership in 2019 has been calculated to be approximately 3.6 million (Burnie, 2020).

Facebook and Twitter are two of the most used social media platforms for news consumption (Shearer \& Gottfried, 2017). Twitter profiles of these newspapers provided information about the number of followers, the date when the newspaper joined Twitter, and a link to the news site. The Facebook profiles were more descriptive, offering information such as the nature of the business, customer service details, and a link to the news site. Newspapers with the largest Facebook following were The New York Times (17.9 million), USA Today (9 million), The Wall Street Journal (6.7 million), New York Post (4.7 million), and Metro (3 million). Newspapers with the largest Twitter following were The New York Times (49.8 million), The Wall Street Journal (18.8 million), USA Today (4.3 million), New York Post (2.1 million), and The Sydney Morning Herald $(836,000)$.

For the analysis we had two units: the Facebook page $(\mathrm{N}=9)$ and the Twitter account of the newspapers $(\mathrm{N}=9)$. For each Facebook page and Twitter account the most recent post or tweet were read and coded until approximately 100 posts and 100 tweets were coded (overall 200 items per newspaper). Overall, the data consisted of screenshots of 904 Facebook posts and 903 Twitter tweets (overall 1807 screenshots). The screenshots were collected between 13th and 26th March 2021. A sampling interval of every third post and tweet was determined and applied.

The codebook and coding were based on the measurement items used by Shin et al. (2015) to identify four organizational relationship cultivation and dialogic communication strategies: disclosure, access, information dissemination, and engagement. These four strategies (i.e., OPR strategies) were identified in our study as categories, and the measurement items identifying these categories were critically reviewed and their suitability as such for this study was evaluated during coding. This was important to do because, in comparison to most types of organizations, media organizations' core business, whether public media or privately owned enterprises, is specialized to disseminate social, economic, and political information to their audiences and is built around constant (hourly and daily) news flows. News organizations are distinct from normal types of organizations in that they are information intermediaries (Deephouse \& Heugens, 2009) positioned at the centre of society-wide information-exchange processes and networks. As such, these infomediaries are formal organizations that provide mediated information to audiences (Hirsch, 1977; Shoemaker \& Reese, 1996). News outlets' core product, therefore, is the news, and these organizations develop strategies to publish (i.e., disseminate) and then promote their product on social media. Figure 1 illustrates the positioning of the last two OPR strategies of information dissemination and engagement within the news business' news production, dissemination, and engagement process.

As a result of this critical reflection of our codes, during the coding process no items related to the access category were found within newspaper posts themselves. In other words, although contact information was made available to the public on the news outlets' social media pages, we did not find contact information published in their posts. When examining how users can contact news outlets directly using the message feature in Facebook and Twitter, we found that, except for New York Post, the Facebook accounts of all selected newspapers allowed users to send a direct message to the newspaper. However, only three (New York Post, USA Today, and The Sydney Morning Herald) out of nine newspapers' Twitter profiles enabled users to send a direct message to the newspaper. The newspapers in our sample are thus more openly accessible on Facebook than on Twitter. Nevertheless, overall it seems that newspapers do not want to be easily accessible. This access strategy is tied to the discussion about media transparency (see Craft \& Heim, 2008). Interestingly, Facebook offers page account holders a "page transparency" feature and some newspapers in our sample have taken advantage of this (e.g., The Sydney Morning Herald). This feature shows users what individual people and organizations are managing the page and whether the page is running advertisements.

Eventually an updated model, which included three categories for the analysis (disclosure, information dissemination, and engagement), was employed for our measurement purposes. In this model information dissemination and disclosure were considered as one-way communication and engagement was considered as two-way dialogical communication. Disclosure and information dissemination categories were related to newspapers' efforts to provide new and interesting information to the general public. The engagement category was related to newspaper efforts to stimulate reactions and conversations on social media.

To measure all categories, we adapted items for each category from the model by Shin et al. (2015). For Facebook posts and Twitter tweets, only one and the most prominent item was selected. The list of items was edited and updated during the coding process as coding screenshots revealed new consistent patterns. After the coding, unused items were discarded from the data set. Also, some new items were formed based on their frequent appearances in the data set. The final list of measurement items according to the three categories is presented in Table 1. 
Table 1. Summary of items used to identify OPR strategies used by newspapers in Facebook and Twitter.

\begin{tabular}{|c|c|c|}
\hline Categories (OPR strategies) & Items in Facebook posts & Items in Twitter tweets \\
\hline Disclosure & $\begin{array}{l}\text { News disclosing journalist(s)' } \\
\text { names/photos }\end{array}$ & News with tagged journalist(s) \\
\hline Information dissemination & $\begin{array}{l}\text { News headlines } \\
\text { ads for or of the company } \\
\text { opinion } \\
\text { live update } \\
\text { photo story } \\
\text { video } \\
\text { podcast/audio } \\
\text { other (food recipe, meme) }\end{array}$ & $\begin{array}{l}\text { News headlines } \\
\text { news about the industry } \\
\text { ads for or of the company } \\
\text { opinion } \\
\text { live update } \\
\text { photo story } \\
\text { video } \\
\text { podcast/audio } \\
\text { other (food recipe, meme, travel, real estate) }\end{array}$ \\
\hline Engagement & $\begin{array}{l}\text { polling/voting } \\
\text { open ended question or sentence } \\
\text { survey } \\
\text { game } \\
\text { registration/signup }\end{array}$ & $\begin{array}{l}\text { polling/voting } \\
\text { open ended question or sentence } \\
\text { survey } \\
\text { game } \\
\text { registration/signup } \\
\text { encourage readers to retweet or reply } \\
\text { retweeted or shared content }\end{array}$ \\
\hline
\end{tabular}

\section{Findings}

Given the high frequency of tweets and Facebook posts published, audiences of these newspapers in our sample were given a lot of opportunities to engage with newspapers on Twitter and Facebook. Newspapers with the highest average number of tweets/day were The Daily Telegraph (105), Metro (89), The Wall Street Journal (68), and USA Today (55). Newspapers with the highest average number of Facebook posts/day were The Daily Telegraph (126), Metro (81), The Sydney Morning Herald (46), and The Wall Street Journal (46). However, our analysis shows that these newspapers rarely asked or encouraged audiences to participate in a discussion about news. Newspapers' requests for audiences to post photos, personal experiences, or comment on the news were only evident in a few posts and tweets. For instance, The Courier-Mail posted a poll on Facebook just four times during the research period; the newspaper also encouraged readers to like a post with a thumbs-up emoji and dislike a post with a sad or angry emoji.

\subsection{Newspapers' Organization-Public Relationships Strategies in Facebook}

We found that newspapers used the information dissemination strategy in Facebook far more than engagement and disclosure. On average, $96 \%$ of Facebook posts published by newspapers in our sample used this strategy. Table 2 shows the breakdown of how the newspapers deployed these strategies via their Facebook account.

In their posts, they mainly concentrated on publishing and promoting the news rather than content-seeking interaction. Other journalistic content like opinions, live updates, and videos were published, although much less frequently. For example, Metro posted a live video of UK Prime Minister Boris Johnson addressing the nation and another video of a disappointed brewery owner who had to pour away beer due to Covid-19 legislation. The total number of posts in the information dissemination category indicates that newspapers used Facebook just to share news (one-way communication). Few newspapers used a disclosure strategy on Facebook. Three newspapers promoted news and opinions with the name or picture of the related journalist, which shows them disclosing to the public some information about their journalists and the nature of the organization. For instance, The Wall Street Journal and The Daily Telegraph displayed the names of journalists who authored news pieces.

On average, only $3 \%$ of Facebook posts of these newspapers used engagement strategies. Newspapers varied in their use of the engagement strategy on Facebook. The most frequent item indicating this strategy on Facebook was an open-ended question in the news headline or as a lead sentence of the post. For instance, The Wall Street Journal used headlines such as "The US Has Followed Europe in Previous Covid-19 Surges. Will It Happen Again?" and "A Surge of Children Crossing the Border. What Happens to Them?" Other ways to engage on Facebook were used only marginally, such as polling or surveying, posting about games, and providing possibilities to register or sign up.

\subsection{Newspapers' Organization-Public Relationships Strategies in Twitter}

As shown in Table 3, the analysis of newspapers' tweets shows more variance between OPR strategies on Twitter 
Table 2. The percentage of nine newspapers' Facebook posts according to categories and sub-categories (measurement items) of OPR strategies.

\begin{tabular}{|c|c|c|c|c|c|c|c|c|c|}
\hline $\begin{array}{l}\text { Category (OPR strategy)/ } \\
\text { sub-category } \\
\text { (measurement items) }\end{array}$ & $\begin{array}{l}\text { The New } \\
\text { York } \\
\text { Times }\end{array}$ & $\begin{array}{l}\text { New } \\
\text { York } \\
\text { Post }\end{array}$ & $\begin{array}{l}\text { USA } \\
\text { Today }\end{array}$ & $\begin{array}{l}\text { The Wall } \\
\text { Street } \\
\text { Journal }\end{array}$ & $\begin{array}{l}\text { The Daily } \\
\text { Telegraph }\end{array}$ & Metro & $\begin{array}{l}\text { The } \\
\text { Sydney } \\
\text { Herald }\end{array}$ & $\begin{array}{l}\text { The Herald } \\
\text { Courier- } \\
\text { Mail }\end{array}$ & $\begin{array}{l}\text { Morning } \\
\text { Sun }\end{array}$ \\
\hline $\begin{array}{l}\text { Information dissemination } \\
\text { (avg }=95,8 \% \text { ) }\end{array}$ & $98 \%$ & $99 \%$ & $98,3 \%$ & $91 \%$ & $90 \%$ & $100 \%$ & $99 \%$ & $95 \%$ & $91 \%$ \\
\hline News headlines & $88 \%$ & $96 \%$ & $84 \%$ & $87 \%$ & $78 \%$ & $89 \%$ & $84 \%$ & $84 \%$ & $62 \%$ \\
\hline Ads for or of the company & & & & $1 \%$ & $1 \%$ & $1 \%$ & & & $3 \%$ \\
\hline Opinion & $3 \%$ & & & $2 \%$ & & & $1 \%$ & & $2 \%$ \\
\hline Live update/coverage & $1 \%$ & & $4,8 \%$ & $1 \%$ & $4 \%$ & & $9 \%$ & & $3 \%$ \\
\hline Photo story & & & & & & $2 \%$ & $2 \%$ & & \\
\hline Video & $3 \%$ & $3 \%$ & $9,5 \%$ & & $6 \%$ & $7 \%$ & $3 \%$ & $7 \%$ & $2 \%$ \\
\hline Podcast/audio & $1 \%$ & & & & & & & & \\
\hline $\begin{array}{l}\text { Other content (food recipe, } \\
\text { meme, real estate, travel, } \\
\text { graphic) }\end{array}$ & $2 \%$ & & & & $1 \%$ & $1 \%$ & & $4 \%$ & $19 \%$ \\
\hline Disclosure (avg = 1,1 \%) & $0 \%$ & $0 \%$ & $0 \%$ & $5 \%$ & $3 \%$ & $0 \%$ & $0 \%$ & $0 \%$ & $2 \%$ \\
\hline $\begin{array}{l}\text { News disclosing journalist(s)' } \\
\text { names/photos }\end{array}$ & & & & $5 \%$ & $3 \%$ & & & & $2 \%$ \\
\hline Engagement (avg = 3,1 \%) & $2 \%$ & $1 \%$ & $1,7 \%$ & $4 \%$ & $7 \%$ & $0 \%$ & $1 \%$ & $4 \%$ & $7 \%$ \\
\hline Polling/voting & & & $0,8 \%$ & & & & & $4 \%$ & \\
\hline $\begin{array}{l}\text { Open ended question } \\
\text { or sentence }\end{array}$ & $2 \%$ & $1 \%$ & $0,9 \%$ & $4 \%$ & $7 \%$ & & $1 \%$ & & $3 \%$ \\
\hline Survey & & & & & & & & $1 \%$ & $1 \%$ \\
\hline Game & & & & & & & & & $2 \%$ \\
\hline Registration/signup & & & & & & & & & $1 \%$ \\
\hline Total & 100 & 100 & 100 & 100 & 100 & 100 & 100 & 100 & 100 \\
\hline $\begin{array}{l}\text { Total number of posts } \\
(\mathrm{N}=904)\end{array}$ & 100 & 100 & 105 & 100 & 100 & 101 & 100 & 100 & 98 \\
\hline
\end{tabular}

than was found in newspapers' Facebook posts. An average of $80 \%$ of newspapers' tweets showed evidence of their use of information dissemination, compared to an average of $96 \%$ on Facebook. An average of $8 \%$ of tweets showed newspapers using disclosure, compared to an average of $1 \%$ on Facebook. An average of $12 \%$ of tweets showed newspapers using engagement, compared to an average of $3 \%$ on Facebook.

The vast majority of these tweets indicated newspapers' use of an information dissemination strategy and therefore as one-way communication with audiences. Newspapers published slightly fewer opinions, live updates, and videos on Twitter than Facebook. Like Facebook, promoting other specialized content (e.g., food recipes, memes, travel tips and real estate presentations) existed on Twitter at a marginal level.

The results show that only one newspaper (The Sydney Morning Herald) employed tagging as an ongo- ing disclosure strategy. The Sydney Morning Herald used the 'at' sign (@) to link to the profile of related journalists or to display the name of the journalist who wrote the article. By tagging news items with journalist(s) who authored them, the newspaper provided information about its news team to the general public. Tagging of journalists within tweets was also used by three other newspapers, but only marginally and not systematically.

Newspapers used an engagement strategy more on Twitter than on Facebook. As a platform, Twitter enables newspapers to be more engaging by retweeting and tagging, which in most cases were the most used items contributing to this strategy. Seven out of nine newspapers used retweeting or sharing others' tweets as part of their engagement strategy. For example, USA Today retweeted tweets of their sports and political news team, local police department, and news editorial's podcast team. However, only three newspapers did this 
Table 3. The percentage of nine newspapers' Twitter tweets according to categories and sub-categories (measurement items) of OPR strategies.

\begin{tabular}{|c|c|c|c|c|c|c|c|c|c|}
\hline $\begin{array}{l}\text { Category (OPR strategy)/ } \\
\text { sub-category } \\
\text { (measurement items) }\end{array}$ & $\begin{array}{l}\text { The New } \\
\text { York } \\
\text { Times }\end{array}$ & $\begin{array}{l}\text { New } \\
\text { York } \\
\text { Post }\end{array}$ & $\begin{array}{l}\text { USA } \\
\text { Today }\end{array}$ & $\begin{array}{l}\text { The Wall } \\
\text { Street } \\
\text { Journal }\end{array}$ & $\begin{array}{l}\text { The Daily } \\
\text { Telegraph }\end{array}$ & Metro & $\begin{array}{l}\text { The } \\
\text { Sydney } \\
\text { Herald }\end{array}$ & $\begin{array}{l}\text { The Herald } \\
\text { Courier- } \\
\text { Mail }\end{array}$ & $\begin{array}{l}\text { Morning } \\
\text { Sun }\end{array}$ \\
\hline $\begin{array}{l}\text { Information dissemination } \\
\text { (avg = } 80 \% \text { ) }\end{array}$ & $82 \%$ & $99 \%$ & $78,5 \%$ & $94 \%$ & $81 \%$ & $73 \%$ & $36 \%$ & $85 \%$ & $91 \%$ \\
\hline News headlines & $72 \%$ & $92 \%$ & $65 \%$ & $90 \%$ & $74 \%$ & $70 \%$ & $26 \%$ & $81 \%$ & $78 \%$ \\
\hline News about the industry & & & & & & & & & $1 \%$ \\
\hline Ads for or of the company & & $1 \%$ & $1 \%$ & $2 \%$ & $3 \%$ & & $2 \%$ & $1 \%$ & $3 \%$ \\
\hline Opinion & & & & & & & $1 \%$ & & $1 \%$ \\
\hline Live update/coverage & $4 \%$ & & & & $2 \%$ & & $7 \%$ & & \\
\hline Photo story & $1 \%$ & & & & & & & & $1 \%$ \\
\hline Video & & $3 \%$ & $12,5 \%$ & $2 \%$ & $2 \%$ & $1 \%$ & & $2 \%$ & \\
\hline Podcast/audio & $2 \%$ & $3 \%$ & & & & & & & \\
\hline $\begin{array}{l}\text { Other content (food recipe, } \\
\text { meme, travel, real estate) }\end{array}$ & $3 \%$ & & & & & $2 \%$ & & $1 \%$ & $7 \%$ \\
\hline Disclosure (avg = 8\%) & $2 \%$ & $0 \%$ & $0 \%$ & $0 \%$ & $0 \%$ & $0 \%$ & $64 \%$ & $4 \%$ & $2 \%$ \\
\hline $\begin{array}{l}\text { News/articles with tagged } \\
\text { journalist(s) }\end{array}$ & $2 \%$ & & & & & & $64 \%$ & $4 \%$ & $2 \%$ \\
\hline Engagement (avg = $12 \%$ ) & $16 \%$ & $1 \%$ & $21,5 \%$ & $6 \%$ & $19 \%$ & $27 \%$ & $0 \%$ & $11 \%$ & $7 \%$ \\
\hline Polling/voting & & & & & & & & $1 \%$ & \\
\hline $\begin{array}{l}\text { Open-ended question } \\
\text { or sentence }\end{array}$ & & & & $2 \%$ & $16 \%$ & & & & $2 \%$ \\
\hline Survey & & & & & & & & & $1 \%$ \\
\hline Game & & & & & $1 \%$ & & & & $2 \%$ \\
\hline Registration/signup & & & & & & & & & $1 \%$ \\
\hline $\begin{array}{l}\text { Encourage readers to } \\
\text { retweet or reply }\end{array}$ & $1 \%$ & $1 \%$ & $1 \%$ & & & & & $4 \%$ & \\
\hline Retweeted or shared content & $15 \%$ & & $20,5 \%$ & $4 \%$ & $2 \%$ & $27 \%$ & & $6 \%$ & $1 \%$ \\
\hline Total & 100 & 100 & 100 & 100 & 100 & 100 & 100 & 100 & 100 \\
\hline $\begin{array}{l}\text { Total number of tweets } \\
(\mathrm{N}=903)\end{array}$ & 100 & 100 & 105 & 99 & 100 & 100 & 99 & 100 & 100 \\
\hline
\end{tabular}

systematically during the data collection period. They used retweeting to promote content their journalists had tweeted earlier or the newspapers' other Twitter profiles (e.g., the newspapers' political team or entertainment team) had tweeted. All other engagement strategy items, excluding open-ended questions or sentences by The Daily Telegraph, were seldom employed and only marginally used among newspapers. Using openended questions in tweets that either dealt with conflicting issues or entertainment, The Daily Telegraph sought to spark discussion in comments and increase the number of clicks. For example, the newspaper used sentences like "Do you agree?", "What do you think?", and "Is this fair?" at the end of its news tweets. The Daily Telegraph also embedded dedicated pictures in its tweets alongside news-related questions such as "Has Meghan and Harry's interview changed your opinion of the royal family?"

Multiple factors could explain the different engagement levels on newspapers' Facebook and Twitter sites. As noted earlier, Twitter is a more news-oriented platform while Facebook is considered more as a social network (Ju et al., 2014; Kalsnes \& Larsson, 2018). Also, Twitter enables retweeting and tagging of posts, which were often used by newspapers. Another reason may be that Twitter users and Facebook users are interested in very different content and levels of engagement. In sum, it would seem that newspapers do not have a well-thought-out strategy for engagement on different platforms. 


\section{Conclusions}

This study examined how some of the most popular newspapers in Australia, the US, and the UK use relationship cultivation and dialogic communication strategies in their Facebook and Twitter accounts. It contributes to media work research with a relational approach to audiences (Coddington et al., 2018; Hepp, 2020; Hepp \& Loosen, 2019; Lewis et al., 2014; Picard, 2011; Villi \& Picard, 2019). Although this research advocates that media organizations should adopt a relational approach to view audiences as relational partners in the mutually beneficial process of news formation, distribution and promotion, this literature has not examined strategies to develop and maintain audience relationships in social media. Thus, our study adopted OPR theory to analyse the strategies used by newspapers to build such relationships via their social media accounts.

Overall, our study's findings show that newspapers do not use very engaging methods in Facebook or Twitter to activate and maintain relationships with their audiences. Instead, newspapers mainly employ an information dissemination strategy on both social media sites, while engagement and disclosure strategies played only a supporting role in their cultivation of organizational relationships with their audiences. The access strategy was almost non-existent, indicating that newspapers do not want to be as accessible as they could be. Most of their Facebook and Twitter posts did not contain any engaging features. Only a few newspapers asked the public to post pictures or encouraged followers to participate in the discussion.

This indicates that although Facebook and Twitter are conducive to media-audience interaction and thus encourage closer relational ties, these newspapers preferred one-way communication with their audiences in these social media sites. It, therefore, seems that newspapers are stuck in the old news dissemination (i.e., publication of news) mindset, even though social media presents opportunities for more two-way communication between newspapers and audiences. This suggests newspaper management and journalists are satisfied with a social media communication model in which they constantly distribute news headlines (with links back to the full stories on their news sites) via their social media sites and rely on their audiences to pass on this news to their social networks, thus contributing to audience consumption and news marketing targets.

This study contributes to online participatory journalism research (see Engelke et al., 2019, for a review of this literature) by providing empirical evidence showing how newspapers are seeking (or not seeking) audience participation in their news distribution practices via social media. We suggest that newspapers' lack of engagement with audiences in social media limits the ability of audience members to enhance a story's prominence and thus draw attention to it (Almgren \& Olsson, 2016; Larsson, 2018). It seems ironic that although audience engage- ment has become a key performance indicator of journalistic production (Cherubini \& Nielsen, 2016), the newspapers in our study did not employ many engagement strategies. We acknowledge that although our measurement of engagement is likely to be different to the way other studies measure engagement, this deserves closer attention in future participatory journalism research into media engagement with audiences.

Given that media organizations, as information intermediaries, are quite different to most other types of organizations, it may at first seem surprising that our main finding, that newspapers predominantly used an information dissemination strategy, correlates closely with the findings of other OPR studies (e.g., Bortree \& Seltzer, 2009; Lovejoy et al., 2012; Rybalko \& Seltzer, 2010; Shin et al., 2015). OPR studies predominantly have examined relationship-cultivation strategies of typical business-to-consumer corporations and non-profit organizations. Shin et al. (2015) examined strategies used by corporations producing different types of products (durable, non-durable and services). However, this is the first known study into how media organizations use OPR strategies in social media.

Our finding that newspapers predominantly used an information dissemination strategy seems fitting at first glance. Indeed, newspapers specialize in the constant dissemination of social, economic, and political information to their audiences. Although a dissemination-first mindset traditionally and predominantly takes place in their proprietary news sites, it seems this practice carries over into social media sites as well. This shows that newspapers do not take seriously the post-dissemination practices linked to engagement (see Dutceac Segesten et al., 2020), particularly distribution, which advances mutually beneficial relations with audience members. We argue that if news outlets want to build closer relations with audience members, they must engage more with audiences in social media.

This study did not adequately investigate media workers' roles and responsibilities in engaging in relational and dialogic communication with audiences in social media. We concur with Malmelin and Villi (2016) that the journalist role of communication facilitator in online communities, in which journalists and other editorial workers seek to inspire discussions about news content, is vital for media organizations aiming to boost market share. Audiences' news-sharing practices, led by these media workers as communication facilitators, contributes to extending the reach of news content and audiences engaging in this content.

There are a number of limitations within our study. First, we disclose that we only looked at engagement strategies of newspapers themselves, not how audiences actually engaged in news content (e.g., we did not consider the quantity of user responses to newspapers' posts). We also did not compare the strategies of newspapers across countries. Another clear limitation is that we did not examine social media posts of other types of 
media organizations, such as television and radio news programs and news magazines. Also, we only examined posts (1807 in total) within a two-week period in March 2021, and thus we did not conduct a longitudinal study, which may have revealed more engagement strategies during highly public events (such as celebrity scandals). Finally, we did not look at the social media profiles and posts of journalists (Holton \& Molyneux, 2018) or of newspapers' subsidiary social media profiles (e.g., political and entertainment news teams). Studies suggest substantial proportions of journalists now hold social media accounts, with Twitter sign-up rates of around $70-80 \%$ in Western countries (Pole \& Gulyas, 2015). Future research may explore these personal journalistic profiles to see if they lead to closer relational ties between journalists and audiences (e.g., Engelke et al., 2019) and between media outlets and audiences. It would also be interesting to explore if relationship cultivation strategies of engagement are dominant in journalists' posts on their social media sites.

\section{Conflict of Interests}

The authors declare no conflict of interests.

\section{References}

Almgren, S., \& Olsson, T. (2016). Commenting, sharing and tweeting news. Nordicom Review, 37(2), 67-81.

Bell, E. (2018, January 21). Why Facebook's news feed changes are bad news for democracy. The Guardian. https://www.theguardian.com/media/media-blog/ 2018/jan/21/why-facebook-news-feed-changesbad-news-democracy

Bell, E., \& Owen, T. (2017). The platform press: How Silicon Valley reengineered journalism. Tow Center for Digital Journalism.

Borger, M., van Hoof, A., \& Sanders, J. (2016). Expecting reciprocity: Towards a model of the participants' perspective on participatory journalism. New Media \& Society, 18(5), 708-725.

Bortree, D. S., \& Seltzer, T. (2009). Dialogic strategies and outcomes: An analysis of environmental advocacy groups' Facebook profiles. Public Relations Review, 35(3), 317-319.

Bruning, S. D., \& Ledingham, J. A. (1999). Relationships between organizations and publics: Development of a multi-dimensional organization-public relationship scale. Public Relations Review, 25, 157-170. https:// doi.org/ckw45t

Burnie, A. (2020). Roy Morgan: SMH, The Age \& AFR on the up following Nine takeover, while print readership overall continues to drop. B\&T. https://www. bandt.com.au/roy-morgan-smh-the-age-afr-on-theup-following-nine-takeover-while-print-readershipoverall-continues-to-drop

Caplan, R., \& boyd, d. (2018). Isomorphism through algorithms: Institutional dependencies in the case of
Facebook. Big Data \& Society, 5(1), 1-12. https://doi: $10.1177 / 2053951718757253$

Cherubini, F., \& Nielsen, R. K. (2016). Digital news project 2016. Reuters Institute for the Study of Journalism.

Coddington, M., Lewis, S. C., \& Holton, A. E. (2018). Measuring and evaluating reciprocal journalism as a concept. Journalism Practice, 12(8), 1-12. https://doi:10. 1080/17512786.2018.1493948

Craft, S., \& Heim, K. (2008). Transparency in journalism: Meanings, merits and risks. In C. G. Wilkins \& C. G. Christians (Eds.), The handbook of mass media ethics (pp. 217-228). Routledge.

De Bussy, N. M. (2010). Dialogue as a basis for stakeholder engagement. In R. L. Heath (Ed.), The SAGE handbook of public relations (pp. 127-144). SAGE.

Deephouse, D. L., \& Heugens, P. P. M. A. R. (2009). Linking social issues to organizational impact: The role of infomediaries and the infomediary process. Journal of Business Ethics, 86(4), 541-553.

Deuze, M. (2007). Convergence culture in the creative industries. International Journal of Cultural Studies, 10(2), 243-63.

Dutceac Segesten, A., Bossetta, M., Holmberg, N., \& Niehorster, D. (2020). The cueing power of comments on social media: how disagreement in Facebook comments affects user engagement with news. Information, Communication \& Society. Advance online publication. https://doi.org/10.1080/ 1369118X.2020.1850836

Engelke, K. M., Hase, V., \& Wintterlin, F. (2019). On measuring trust and distrust in journalism: Reflection of the status quo and suggestions for the road ahead. Journal of Trust Research, 9(1), 66-86.

Gans, H. (1979). Deciding what's news: A study of CBS Evening News, NBC Nightly News, Newsweek, and Time (visions of the American press). Northwestern University Press.

Grunig, J. E., \& Huang, Y. H. (2000). From organizational effectiveness to relationship indicators: Antecedents of relationships, public relations strategies, and relationship outcomes. In J. A. Ledingham \& S. D. Bruning (Eds.), Public relations as relationship management: A relational approach to the study and practice of public relations (pp. 23-53). Lawrence Erlbaum Associates.

Hansen, L. K., Arvidsson, A., Nielsen, F. A., Colleoni, E., \& Etter, M. (2011). Good friends, bad news-Affect and virality in Twitter. Future Information Technology Communications in Computer and Information Science, 185, 34-43.

Harte, D., Williams, A., \& Turner, J. (2017). Reciprocity and the hyperlocal journalist. Journalism Practice, $11(2 / 3), 160-176$.

Hepp, A. (2020). The fragility of curating a pioneer community: Deep mediatization and the spread of the quantified self and maker movements. International Journal of Cultural Studies, 23(6), 932-950.

Hepp, A., \& Loosen, W. (2019). Molo.news: Experimen- 
tally developing a relational platform for local journalism. Media and Communication, 7(4), 56-67.

Hermida, A. (2020). Post-publication gatekeeping: The interplay of publics, platforms, paraphernalia, and practices in the circulation of news. Journalism \& Mass Communication Quarterly, 97(2), 469-491.

Hesmondhalgh, D., \& Baker, S. (2011). Creative labour. Media work in three cultural industries. Routledge.

Hirsch, P. M. (1977). Occupational, organizational and institutional models in mass communication. In P. Hirsch, P. V. Miller, \& F. G. Kline (Eds.), Strategies for communication research (pp. 13-42). SAGE.

Holton, A. E., \& Molyneux, L. (2018). Social media and journalistic branding. Explication, enactment, and impact. In B. Franklin \& S. Eldridge II (Eds.), The Routledge handbook of developments in digital journalism studies (pp. 441-449). Routledge.

Holton, A. E., Lewis, S. C., \& Coddington, M. (2016). Interacting with audiences: Journalistic role conceptions, reciprocity, and perceptions about participation. Journalism Studies, 17(7), 849-859.

Hon, L. C., \& Grunig, J. (1999). Guidelines for measuring relationships in public relations. The Institute for Public Relations. https://www.institutefor pr.org/wp-content/uploads/Guidelines_Measuring_ Relationships.pdf

Ju, A., Jeong, S. H., \& Chyi, H. I. (2014). Will social media save newspapers? Examining the effectiveness of Facebook and Twitter as news platforms. Journalism Practice, 8(1), 1-17.

Kalsnes, B., \& Larsson, A. O. (2018). Understanding news sharing across social media: Detailing distribution on Facebook and Twitter. Journalism Studies, 19(11), 1669-1688.

Kelleher, T. (2009). Conversational voice, communicated commitment, and public relations outcomes in interactive online communication. Journal of Communication, 59, 172-188.

Kent, M. L., \& Taylor, M. (1998). Building dialogic relationships through the world wide web. Public Relations Review, 24(3), 321-334.

Ki, E.-J., \& Hon, L. C. (2009). A measure of relationship cultivation strategies. Journal of Public Relations Research, 21(1), 1-24.

Larsson, A. O. (2018). The news user on social media. A comparative study of interacting with media organizations on Facebook and Instagram. Journalism Studies, 19(15), 2225-2242.

Ledingham, J. A., \& Bruning, S. D. (1998). Relationship management and public relations: Dimensions of an organization-public relationship. Public Relations Review, 24(1), 55-65.

Ledingham, J. A., Bruning, S. D., \& Wilson, L. J. (1999). Time as an indicator of the perceptions and behavior of members of a key public: Monitoring and prediction organization-public relationships. Journal of Public Relations Research, 11, 167-183.

Lehtisaari, K., Villi, M., Grönlund, M., Linden, C.-G.,
Mierzejewska, B. I., Picard, R. G., \& Röpnack, A. (2018). Comparing innovation and social media strategies in Scandinavian and US newspapers. Digital Journalism, 6(8), 1029-1040.

Lewis, S. C., Holton, A., \& Coddington, M. (2014). Reciprocal journalism: A concept of mutual exchange between journalists and audiences. Journalism Practice, 8(2), 229-241.

Lewis, S. C., \& Molyneux, L. (2018). A decade of research on social media and journalism: assumptions, blind spots, and a way forward. Media and Communication, 6(4), 11-23.

Lillqvist, E., \& Louhiala-Salminen, L. (2014). Facing Facebook: Impression management strategies in company-consumer interactions. Journal of Business and Technical Communication, 28(1), 3-30.

Lovejoy, K., Waters, R. D., \& Saxton, G. D. (2012). Engaging stakeholders through Twitter: How non-profit organizations are getting more out of the 140 characters or less. Public Relations Review, 38, 313-318.

Malmelin, N., \& Villi, M. (2016). Audience community as a strategic resource in media work: Emerging practices. Journalism Practice, 10(5), 589-607.

Malmelin, N., \& Villi, M. (2017). Media work in change: Understanding the role of media professionals in times of digital transformation and convergence. Sociology Compass, 11(7), Article e12494. https:// doi:10.1111/soc4.12494

Mayhew, F. (2020, February 20). National newspaper ABCs: Daily Star Sunday sees biggest print drop in first 2020 circulation figures. PressGazette. https:// www.pressgazette.co.uk/national-newspaper-abcdaily-star-sunday-print-drop-first-2020-circulationfigures

Meese, J., \& Hurcombe, E. (2020). Facebook, news media and platform dependency: The institutional impacts of news distribution on social platforms. New Media \& Society, 23(8), 2367-2384. https://doi. org/10.1177/1461444820926472

Meyer, R. (2013, December 8). Why are upworthy headlines suddenly everywhere? The Atlantic. http://www.theatlantic.com/technology/archive/ 2013/12/why-are-upworthy-head-lines-suddenlyeverywhere/282048

Napoli, P. M. (2009). Navigating producer-consumer convergence: Media policy priorities in the era of usergenerated and user-distributed content. The Donald McGannon Communication Research Center, Fordham University.

Newman, N., Fletcher, R., Schulz, A., Andı, S., Robertson, C. T., \& Nielsen, R. S. (2021). Digital news report 2021. Reuters Institute for the Study of Journalism. https://eur03.safelinks.protection.outlook.com/ ?url=https\%3A\%2F\%2Freutersinstitute.politics.ox.ac. uk\%2Fdigital-news-report\%2F2021\&amp;data $=04$ \%7C01\%7C\%7Cb47ff6642e574f8edb7808d93bd 2838c\%7Ce9662d58caa44bc1b138c8b1acab5a11\% 7C1\%7C0\%7C637606597620731307\%7CUnknown 
\%7CTWFpbGZsb3d8eyJWIjoiMC4wLjAwMDAiLCJQ ljoiV2luMzliLCJBTil6Ik1haWwiLCJXVCI6Mn0\%3D \%7C1000\&amp;sdata=YtzIC2eyPExmBfo4AV14z JBkbJABjrUAdjrsWUvkLho\%3D\&amp;reserved $=0$

Nielsen, R. K., \& Schrøder, K. C. (2014). The relative importance of social media for accessing, finding, and engaging with news: An eight-country crossmedia comparison. Digital Journalism, 2(4), 472-489. https://doi.org/10.1080/21670811.2013.872420

Oeldorf-Hirsch, A., \& Sundar, S. S. (2012, August 9-12). Engagement with news content in online social networks [Paper presentation]. 95th Annual Conference of the Association for Education in Journalism and Mass Communication, Chicago, USA.

Oremus, W. (2016, January 3). Who controls your Facebook feed. Slate. http://www.slate.com/articles/ technology/cover_story/2016/01/how_facebook_ s_news_feed_algorithm_works.html

Picard, R. G. (2011). The economics and financing of media companies (2nd ed.). Fordham University Press.

Pole, K., \& Gulyas, A. (2015). Social journalism study 2015 United Kingdom. Cision Germany.

Reader, B. (2018). Despite losses, community newspapers still dominate the US market. Newspaper Research Journal, 39(1), 32-41.

Rybalko, S., \& Seltzer, T. (2010). Dialogic communication in 140 characters or less: How fortune 500 companies engage stakeholders using Twitter. Public Relations Review, 36(4), 336-341. https://doi.org/10.1016/ j.pubrev.2010.08.004

Sallot, L. M., Lyon, L. J., Acosta-Alzuru, C., \& Jones, K. O. (2003). From aardvark to zebra: A new millennium analysis of theory development in public relations academic journals. Journal of Public Relations Research, 15(1), 27-90. https://doi:10.1207/ S1532754XJPRR1501_2

Shearer, E., \& Gottfried, J. (2017). News use across social media platforms 2017. Pew Research Center. https://www.pewresearch.org/journalism/2017/ 09/07/news-use-across-social-media-platforms2017

Shearer, E., \& Grieco, E. (2019). Americans are wary of the role social media sites play in delivering the news. Pew Research Center. https://www.journalism.org/ 2019/10/02/americans-are-wary-of-the-role-socialmedia-sites-play-in-delivering-the-news

Shin, W., Pang, A., \& Kim, H. J. (2015). Building relationships through integrated online media: Global organizations' use of brand web sites, Facebook, and Twitter. Journal of Business and Technical Communication, 29(2), 185-220.

Shoemaker, P. J., \& Reese, S. D. (1996). Mediating the message: Theories of influences on mass media content. Longman.

Statista. (2019). Leading daily newspapers in the United States in September 2017 and January 2019, by circulation. https://www.statista.com/statistics/184682/ us-daily-newspapers-by-circulation

Villi, M., Matikainen, J., \& Khaldarova, I. (2016). Recommend, tweet, share: User-distributed content (UDC) and the convergence of news media and social networks. In A. Lugmayr \& C. Dal Zotto (Eds.), Media convergence handbook. Journalism, broadcasting, and social media aspects of convergence (Vol. 1, pp. 289-306). Springer.

Villi, M., \& Noguera-Vivo, J. M. (2017). Sharing media content in social media: The challenges and opportunities of UDC (user-distributed content). Journal of Applied Journalism \& Media Studies, 6(2), 207-223.

Villi, M., \& Picard, R. G. (2019). Transformation and innovation of media business models. In M. Deuze \& $\mathrm{M}$. Prenger (Eds.), Making media. Production, practices, and professions (pp. 121-131). Amsterdam University Press.

Wilcox, D. L., \& Cameron, G. T. (2009). Public relations strategies and tactics (9th ed.). Pearson Allyn \& Bacon.

\section{About the Authors}

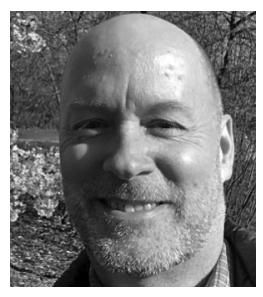

Mark Badham (PhD) is senior lecturer in corporate communication at Jyväskylä University School of Business \& Economics, Finland. His research is focused on news media roles in mass communication processes, digital crisis communication, social media engagement, relationship management, and organizational legitimacy.

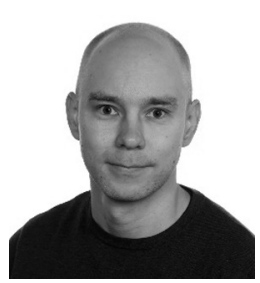

Markus Mykkänen (PhD) is a postdoctoral researcher at the Department of Languages and Communication Studies in the University of Jyväskylä. His earlier research has focused on organizational decision making, public relations, crisis communication, and media influence of think tanks. His current research interests include the role of the news media and political journalists in advocacy and lobbying. 